\title{
The Relationship Between the Strategic and Growth Factors of Enterprise: Data of Mexico (Empirical Evidence)
}

\author{
Luís Aguilera Enríquez, Martha González Adame, R. Rodrigo Rodríguez Camacho \\ Universidad Autónoma de Aguascalientes, Aguascalientes, México
}

\begin{abstract}
The growth has been studied from multiple angles and varied approaches so it is a factor that must be evaluated in micro, small and medium-sized enterprises (SMEs) in order to make decisions that improve their results. In the same way, the creation of strategies need a deep situational analysis, it is equally important to the efficiency and effectiveness of such strategies so they become operational. The central question addressed in the present study was identifying the variables that provide its own validity and, secondly, to determine which variables have a higher impact on the response variable (sales). The survey contains 159 items in 58 grouped questions. The collected data from a sample of 109 enterprises from different sectors and sizes were codified in order to carry out general descriptive procedures. The reliability of the instrument showed a Cronbach's alpha value of 0.8 . The main statistical method used was the regression analysis. In order to carry it out, six compound variables were entered for the factors of information technologies, innovation, trading efforts, human resources, quality and technology. The results reveal that the more prepared the manager is and the more effectiveness obtained from the training program then the better indicators of growth will be obtained as a result (i.e. sales). The more integration among quality indicators (development of specifications and cost reduction programs) is, the better levels of growth (i.e. sales and growth perception) will be. The information technologies must be analyzed by the enterprises because once they are classified by their size, it is possible to observe a positive and significant correlation in any of the two ways of measuring the company's growth. The results can be useful for the people in charge of key decisions in any kind of enterprise as it displays a theoretical background for identify their main competitive variables.
\end{abstract}

Keywords: strategies, SMEs, sales growth, innovation and competitiveness

\section{Introduction}

The knowledge on the behavior of the productive sectors in Mexico is useful to understand the dynamics of the factors that promote the growth of economic activities and strengthens the process of decision making.

Luís Aguilera Enríquez, Ph.D., Administración, Centro de Ciencias Economicas y Administrativas, Universidad Autónoma de Aguascalientes.

Martha González Adame, Ph.D., Administración, Centro de Ciencias Economicas y Administrativas, Universidad Autónoma de Aguascalientes.

R. Rodrigo Rodríguez Camacho, Ph.D., Administración, Centro de Ciencias Economicas y Administrativas, Universidad Autónoma de Aguascalientes.

Correspondence concerning this article should be addressed to Luís Aguilera Enríquez, Universidad Autónoma de Aguascalientes, Av Universidad 940 edif 32, Ciudad Universitaria. CP 20131 Aguascalientes, Ags, México. E-mail: laguiler@correo.uaa.mx. 
Cuervo (2004) established that the creation of wealth and the dynamism of a country were based on the competitiveness of their enterprises, which depend basically on the abilities of the businessmen and CEOs.

Mexico is in an economic situation that is far from satisfying the needs related to job creation, sustained growth, and creation of development opportunities for its inhabitants. In order to understand the real perspective of the nation, it is necessary to analyze the different regional situations and their growth perspectives (see Table 1).

Table 1

Specific Weight Per Economic Sector in Aguascalientes

\begin{tabular}{lcc}
\hline Sector & Percentage of Economic Unit & Percentage of job \\
\hline Fishing & \multicolumn{1}{c}{ - } & - \\
Mining, oil, and gas extraction & 0.1 & 0.4 \\
Manufacturing & 10.2 & 33.8 \\
Electricity, water, and gas & 0.0 & 0.8 \\
Construction & 0.8 & 5.8 \\
Commerce & 50.7 & 28.9 \\
Transportation, mailing, and storage & 1.9 & 2.9 \\
Financial services & 0.3 & 0.2 \\
Non-financial services & 36.0 & 27.2 \\
Total & $100 \%$ & $100 \%$ \\
\hline
\end{tabular}

Note. Source: INEGI (2010).

Sánchez (2009) stated that the international financial crisis was forcing everyone to reflect about the future of the Mexican micro, small and medium-sized enterprises (SMEs) in the context of the reaction perceived by the Mexican government through a public policy that in 2009 attempted to reactivate the economy by means of an increased participation in the economy (see Table 2). It is important to understand that SMEs play an important social role as they are an instrument of social cohesion and stability by creating job opportunities (either formal or informal jobs) for people with or without professional education.

Table 2

Main Economic Branches and Their Importance in Aguascalientes

\begin{tabular}{lc}
\hline Economic branch & National rank \\
\hline Manufacture of communication equipment & 2 \\
Manufacture of machinery and equipment for trading and services & 2 \\
Manufacture of electronic components & 3 \\
Manufacture of cars and trucks & 5 \\
Auto transport of specialized cargo & 5 \\
Manufacture of clothing items & 8 \\
Manufacture of spare part for motor vehicles & 10 \\
Manufacture of plastic products & 13 \\
\hline
\end{tabular}

Note. Source: INEGI (2010).

Aguascalientes State (with a little over one million inhabitants) ranks in the 28th place of the national population with a mean annual population growth of $2.1 \%$ (above the national mean which is $1 \%$ ). It also has $33.7 \%$ of the population under 15 years old (above the national mean which is $30.6 \%$ ). 
With regard to the economic aspects, the amount of the population that is 14 years or older and available for economic activities is $\mathbf{5 7 . 4 \%}$ (below the national mean which is $58.1 \%$ ). This ranks Aguascalientes State in the 26th place related to the amount of the population that does not obtain income which is $4.5 \%$ (below the national mean which is 58.1\%) (INEGI, 2009).

It can be seen in Table 3 that the manufacturing sector, the metal-mechanics sector (i.e., the production of cars, trucks, and spare parts), the textile sector and the retail sector represent economic activities that can be considered as the main force in the economy of Aguascalientes State either by its participation in the economic activities, the amount of jobs created or by its importance at a national level.

Table 3

Main Characteristics of the Economic Units

\begin{tabular}{lcccc}
\hline National & Manufactures Trading & Non-financial private services & The other sectors \\
\hline Economic units ot. $=$ 3,735,347 & 435,436 & $1,869,120$ & $1,351,477$ & 79,314 \\
Employed personnel ot. $=20,254,726$ & $4,522,799$ & $6,183,596$ & $6,957,240$ & $2,591,082$ \\
Aguascalientes & & & & 16,648 \\
Economic units ot. $=41,064$ & 4,170 & 19,488 & 858 \\
Employed personnel ot. $=246,372$ & 69,015 & 69,867 & 85,761 & 21,729 \\
\hline
\end{tabular}

Note. Source: Censos Económicos (2009).

Table 4 shows that Manufacturing companies, business trade and non-financial private services represent the main economic activities at both national and state levels.

Table 4

Distribution of Enterprises by Their Size (National and Aguascalientes State)

\begin{tabular}{|c|c|c|c|c|}
\hline National & Micro & Small & Medium size & Big \\
\hline \multirow{2}{*}{ Economic units } & $3,550,472$ & 147,435 & 30,142 & 7,298 \\
\hline & $95.1 \%$ & $3.9 \%$ & $0.8 \%$ & $0.2 \%$ \\
\hline \multirow{2}{*}{ Employed personnel } & $8,418,441$ & $3,032,770$ & $3,126,380$ & $5,677,135$ \\
\hline & $41.6 \%$ & $15.0 \%$ & $15.4 \%$ & $28.0 \%$ \\
\hline Aguascalientes & Micro & Small & Medium size & Big \\
\hline \multirow{2}{*}{ Economic units } & 38,503 & 2,068 & 402 & 91 \\
\hline & $93.8 \%$ & $5.0 \%$ & $1.0 \%$ & $0.2 \%$ \\
\hline \multirow{2}{*}{ Employed personnel } & 98,992 & 42,628 & 41,159 & 63,583 \\
\hline & $40.2 \%$ & $17.3 \%$ & $16.7 \%$ & $25.8 \%$ \\
\hline
\end{tabular}

Note. Source: INEGI (2010).

The reader can find in Table 5, the most significant results obtained from the survey which was done to 109 businessmen in Aguascalientes State, who are the subjects of study in this research. Some data collected include: structure, technology, management skills, decision-making, certification processes, innovation and development, kinds of markets, technological research and development, public policy, trademarks and patents, and need of competitive improvement.

There are disagreements related to the aspect of growth. Three out of all the analyzed sectors have had an important growth in their operations whereas the other three sectors have not gone beyond the five percent of 
growth. This, unfortunately, represents important sectors in the economy of the state such as services, manufacturing of furniture and the textile industry.

Table 5

Most Important Results From the Diagnosis

\begin{tabular}{|c|c|}
\hline $\begin{array}{l}\text { Competitiveness } \\
\text { indicator }\end{array}$ & Result \\
\hline Structural data & $\begin{array}{l}\text { The enterprises that create a business plan have the vision to consider their potential about facilities since } \\
\text { the beginning of their operations because they include in their plan future clients that can make their } \\
\text { operations a reality. However, in the real life, these enterprises solely take advantage of this in } 60 \% \text { or } \\
70 \% \text {. }\end{array}$ \\
\hline Techonology & $\begin{array}{l}\text { From all the functional areas that an enterprise can have in any of the integrated economical sectors of } \\
\text { Aguascalientes, the most used systems are accounting, purchases and sales plans. The rest of the systems } \\
\text { that could be integrated are only used in a rudimentary way when compared to the current software. }\end{array}$ \\
\hline Management skills & $\begin{array}{l}\text { In the enterprises that have been analyzed for this research, it has been proved that, regardless of the } \\
\text { personal skills, there is a lack of methodologies that can strengthen decision-making or the application of } \\
\text { tools that improve the growth and productivity of the operations that the enterprise may need. }\end{array}$ \\
\hline $\begin{array}{l}\text { Information } \\
\text { technologies for } \\
\text { decision-making }\end{array}$ & $\begin{array}{l}\text { Nowadays, enterprises relate this activity with the directive board, the owner of the company or the } \\
\text { person in charge that is on top of the organization chart. Departmental areas are rarely authorized to carry } \\
\text { out this activity and this can be seen in all the investigated sectors and in all the kinds of business. }\end{array}$ \\
\hline $\begin{array}{l}\text { Problems that must be } \\
\text { faced }\end{array}$ & $\begin{array}{l}\text { Training of headmen, constant improvement of their processes, the integration of certification processes, } \\
\text { improvement of information technologies and improvement of growth strategies for the enterprise. }\end{array}$ \\
\hline Certification processes & $\begin{array}{l}\text { The enterprises that have been studied in this research show a high percentage related to the lack of } \\
\text { knowledge to the kinds of certification and the lack of automation in their processes. Even the enterprises } \\
\text { that have good quality products and services do not have a record or a control in the process of quality. } \\
\text { This also reflects a lack of cultural and organizational commitment with the operations management as } \\
\text { well as the inherent activities of the post. }\end{array}$ \\
\hline $\begin{array}{l}\text { Innovation } \\
\text { development }\end{array}$ & $\begin{array}{l}\text { Aguascalientes State develops its activities in the local, regional, national and international markets. The } \\
\text { local market represents the biggest percentage according to the analyzed sectors. There is a significant } \\
\text { variation in the textile sector regarding the aspect of exports, which gives a constant presence in a very } \\
\text { competitive market. }\end{array}$ \\
\hline $\begin{array}{l}\text { Needs of competitive } \\
\text { improvement }\end{array}$ & $\begin{array}{l}\text { It is important to consider team work, research and development in everything that is vital for the } \\
\text { recovery of competitiveness and growth so the enterprises of Aguascalientes can be developed. Another } \\
\text { tool that is designed for the growth of quality, safety, productivity and cost control is the constant } \\
\text { improvement, an aspect that is mostly not implemented in the enterprises from any sector studied in this } \\
\text { research. }\end{array}$ \\
\hline $\begin{array}{l}\text { Research } \\
\text { technological } \\
\text { development }\end{array}$ & $\begin{array}{l}\text { Regarding this aspect, the enterprises in Aguascalientes State (specifically the ones of manufacturing and } \\
\text { metal-mechanics) still have old equipment. The average of new equipment that is used is rather low in } \\
\text { most enterprises. Only medium-sized or big companies include this area in their organization chart which } \\
\text { allows them to be updated in the technological development. }\end{array}$ \\
\hline $\begin{array}{l}\text { Human resources } \\
\text { control and knowledge }\end{array}$ & $\begin{array}{l}\text { The analyzed enterprises shows in terms of management that the administrators are mostly between } 45 \\
\text { and } 55 \text { years old, with a bachelor's degree, an experience of around five years and the use of only one } \\
\text { language. They know the basics of English language, but not enough to make a research or consultation. } \\
\text { From the sample of this research, only one percent knows three languages, } 15 \% \text { has a master's degree and } \\
5 \% \text { have a Ph.D.. This gives as a result that there is a substantial lack of adequate techniques in order to } \\
\text { drive the company in the right direction in economic aspects such as the development and growth. }\end{array}$ \\
\hline $\begin{array}{l}\text { Government } \\
\text { policies }\end{array}$ & $\begin{array}{l}\text { Aguascalientes State has financial support programs for enterprises in any sector and category. However, } \\
\text { the owners or managers do not know the programs or the necessary paperwork in order to obtain the } \\
\text { benefits, which is an important element that may decide the company's growth. That is why it is } \\
\text { important to get in touch with the government areas that are related to the productive sector and grab the } \\
\text { opportunities that help the enterprise in its development. }\end{array}$ \\
\hline Trademarks and patents & $\begin{array}{l}\text { The enterprises that are settled in Aguascalientes are mostly unregistered in their trademarks and patents, } \\
\text { which show an evident risk of losing their intellectual property. As a consequence, the competition could } \\
\text { take advantage of this intellectual development. It is important to train the managers to integrate, as part } \\
\text { of their priorities, the habit of developing and registering any product or service that is created inside the } \\
\text { company. }\end{array}$ \\
\hline
\end{tabular}

Note. Source: Aguilera (2009). 
Table 6

Comparative Growth of the Enterprise

\begin{tabular}{lllllll}
\hline Growth/sector & Foods & Trading and services & Manufacturing & Metal-mechanics & Furniture & Textile and clothing \\
\hline Below 5\% & $15 \%$ & $31.30 \%$ & $18.20 \%$ & $16.70 \%$ & $58.30 \%$ & $45.50 \%$ \\
From 5\% to 10\% & $15 \%$ & $28.10 \%$ & $18.20 \%$ & $16.70 \%$ & $16.70 \%$ & $18.20 \%$ \\
From 10\% to 20\% & $25 \%$ & $18.80 \%$ & $0 \%$ & $25 \%$ & $16.70 \%$ & $18.20 \%$ \\
Over 20\% & $40 \%$ & $21.90 \%$ & $63.60 \%$ & $33.30 \%$ & $0 \%$ & $13.60 \%$ \\
\hline
\end{tabular}

Table 6 shows the growth percentages of SMEs in the last three years of operation.

To explore this research topic, the paper includes these part: the theory and hypothesis; the research design; the discussion of results; the conclusion and the references.

\section{Theory and Hypothesis}

\section{Business Strategies}

Andrews (1998) defined the concept of strategy as a pattern of decisions in a company that determines the objectives and goals by creating plans and policies in order to achieve them by considering the economic and human factors so it benefits the share holders, employees, clients, and the community.

Haugstad (1999) pointed out the essence of a business by emphasizing the search of long-term competitive advantages in each one of the commercial activities related to the strengths and weaknesses of the enterprise as well as the threats and opportunities of the competitive environment.

For Munive, Dewhurst, Pritchard, and Barber (2004), there are two main tendencies in the creation and design of strategies: the deliberate strategies (the ones that must have been planned to be implemented later on) and those that refer to the incremental learning (where the strategy is considered as a modification or adaptation of knowledge that already exists in order to find solutions to emerging situations). Thus, the idea that the organizations have some sort of strategy can be defined as the group of actions that an organization looks for in order to achieve its objectives (Beaver, 2007) and this enables an encouraging and positive environment for the organizational development.

Strategies lead decisions and allow the operative plans to take place accordingly along with the achievement of the company's objectives in order to increase the possibility of fulfilling the objectives and goals.

Burgelman (2002) defined strategy as the theory that the directive board had as the platform for the past and future success. This concept indicates that the necessary actions to take the organization from what it is to what it wants to be in the future lies in the nature of the strategy as a relationship of cause and effect between the wanted performance and all the factors that influence it.

Therefore, a strategy can be defined as a pattern of action or plan that, along with the political goals and the company's values as a whole, allows the use of resource for the strengthening of competences in a competitive business environment where the rivals center their efforts and thus the achievement of competitive advantages to put the product or service within the consumers’preferences (Quinn \& Voyer, 1998).

\section{Competences and Resources}

In order to understand the mechanisms used to create and formulate strategies for an organization, it is necessary to mention that the first step is, undoubtedly, an analysis of the resources, capacities, competences, 
capital, raw material and in general all the resources used in the enterprise as well as excluding their own objectives with the expectations created by the employees, consumers, suppliers, share holders, and the community, with the requirements imposed by government policies. After this, an analysis of the conditions about the industry and the specific sector where the enterprise perform their activities is carried out. In this way, it is possible to determine the characteristics of the competitors and suppliers as well as their individual strengths and weaknesses.

The information obtained is then compared with the company's own capacities and the ones from other economic agents in order to evaluate their orientation, values and main purpose to achieve a general profile of the necessary steps to carry out in the industry. Just in the same way that the creation of strategies need a deep situational analysis, it is equally important to observe the efficiency and effectiveness that make them operational. When an enterprise obtains higher standards than the ones of its competitors, the most important element is not the magnitude of the positive results but the efforts taken to keep and consolidate the competitive advantage.

Hamel and Prahalad (1994) argued that if an enterprise is not the first one to introduce an innovation, it is a consequence of not having the necessary competences and capacities. The authors defined the concept of core competences as a way to measure leadership and success of the company by means of its costs level, technological degree, infrastructure, business knowledge, productive ability, management of the supplying chain as well as skills and knowledge of the directive board and operational personnel. That is why these aspects make the difference because other competitors cannot duplicate them easily and this allows the aspects to be profitable in the long term. However, just a few companies have more than six fundamental competences because it would imply an enormous effort that requires skills and knowledge beyond their competitors.

That is why each enterprise will have specific characteristics that are related to the variation of performance as they are entangled in their own organizational routines (Hamel, 1996; Penrose, 1959).

Thus, core competences can be defined as an interdependent knowledge system that provides a competitive advantage that contains four dimensions (Álvarez, 2003): knowledge and skills from employees; technical systems; leading systems as well as policies and values associated to the control of knowledge.

This is supported by the principles established by Barney (1991), who identified the company resources as the factors that will help to face the changes and opportunities that the business environment can offer. The author takes the idea as a starting point that the resources are heterogenic and they have limited mobility in the enterprises. In this way, they can be classified in physical resources, human resources and the resources related to organizational capital. However, the author also highlights the idea that the strategies, in order to be effective, must be "unique"; that is, strategies that are not being used by any other competitor at the same time. Besides this, the discontinuation of the strategy is determined by the response of other competitors.

\section{Business Growth}

After earlier attempts to define the concept of growth were made by Penrose (1952), who developed a theory about internal growth, rather than mergers and acquisitions, a great number of articles have appeared discussing different aspects of the same variable.

One of the current characteristics of Mexico shows that most of the small enterprises focus their property and management only on the owner-manager character (assisted sometimes by other family members), who takes 
the key role of leader in the organization by centralizing most of the strategic decisions (BID-IKEI, 2005).

This is a situation that does not always allow taking advantage of the opportunities mentioned earlier, where another kind of opportunity is created: business alliance. Taboada (2004) explained that understanding the reasons why an enterprise can find more convenient to cooperate with another, rather than producing or buying, which is important for the economic theory. Businessmen need to accept their internal weaknesses so they can look for alliance opportunities to work together with other enterprises in the production and introduction of a product or service in the market, the development of capacities and competitive advantages within a model of mutual respect of the values and objectives of each organization. Blázquez, Dorta, and Verona (2006) established that one of the main objectives of the enterprises was the creation of value for owners and the return of utilities based on the investment (within a model of respect to the institutions and legal framework as well as the relationship with employees, clients, and suppliers).

Table 7

Indicators to Measure the Company's Growth

\begin{tabular}{|l|l|}
\hline Ways to measure growth & Author/Year \\
\hline Number of employees & $\begin{array}{l}\text { Evans (1987), González Núñez (1988), Kraybill \& Variyam } \\
\text { (1992), Ocaña et al. (1994), Becchetti \& Trovato (2002) }\end{array}$ \\
\hline Sales volumen & Petrakis (1997) \\
\hline Net investment & $\begin{array}{l}\text { Maroto Acín (1996), Schianterelli (1996), López Gracia et } \\
\text { al. (1999), Raymond et al. (1999) }\end{array}$ \\
\hline Gross investment & Mato (1989) \\
\hline Difference between market value and countable value of the enterprise & Varaiya et al. (1987) \\
\hline Sales volume and added value & Maravall (1984) \\
\hline Sales volume and total active & Chittenden et al. (1996) \\
\hline Net total active, exploitation income and added value & González Pérez \& Correa Rodríguez (1998) \\
\hline Number of employees, sales and total active & Lang et al. (1996), Heshmati (2001) \\
\hline Number of employees, sales and affordability & Birley \& Westhead (1990) \\
\hline Number of employees, sales volume, total active and added value & Calvet et al. (1989) \\
\hline Number of employees, sales volume, own funds and added value & Antón Martín et al. (1990) \\
\hline Multi-criterion value & $\begin{array}{l}\text { Bueno Campos et al. (1984), Bueno Campos \& Lamothe } \\
\text { Fernández (1986), Correa Rodríguez (1999), Correa } \\
\text { Rodríguez et al. (2001) }\end{array}$ \\
\hline
\end{tabular}

The essence of the modern enterprise, as defined by Cuervo (2004), is the specialization of functions where the businessmen lead and control the economic activity.

Aragón Sánchez (2005) stated that the company's ability to obtain higher results depends mainly on the capacity to acquire and coordinate resources in order to place the enterprise within the theory of resources and capacities as the central analysis of business competitiveness. The author also defends the idea that the enterprise's capacity to become successful in the markets will depend mainly on the resources it has and their management.

On the other hand, Rojo and González (2007) considered that business growth was motivated mainly by a need of survival, which forced businessmen to understand that a change in the ways to develop their own competitive advantages was absolutely necessary if one takes into consideration that the growth comes from new investments in the same company or by the acquisition, participation or creation of agreements with other 
companies.

However, the way to measure the variable of growth made by Blazques et al. (2006) has different perspectives.

Each way to measure business growth implies different sources of information (see Table 7) and depends on the availability that each enterprise has on the involved variables. This paper attempts to analyze the factors that have an impact on the variable of growth as an indirect indicator of the enterprise's competitiveness.

\section{Research Design}

The distribution of enterprises by activities (see Table 8), according to the Ministry of Economy (2009), was used as a basis for the survey that was implemented under the procedure of stratified sampling.

Table 8

Sectors of the Analyzed Enterprises in Aguascalientes State

\begin{tabular}{llllll}
\hline \multicolumn{2}{l}{ Questionnaires sent: 567} & \multicolumn{5}{l}{ Questionnaires answered: 109} \\
\hline Foods & Textile & Manufactures & Trading and services & Metal-mechanics & Furniture \\
20 & 22 & 11 & 32 & 12 & 12 \\
$18.3 \%$ & $20.2 \%$ & $10.1 \%$ & $29.4 \%$ & $11.0 \%$ & $11.0 \%$ \\
\hline
\end{tabular}

Note. Source: Ministry of Economy (2009).

The survey contains 159 items in 58 grouped questions. The collected data obtained from the survey were codified with the SPSS software in order to carry out general descriptive procedures (mean, standard deviation, variable dependency and graphics that represent the grouping of the cases in each variable). The reliability of the instrument showed a Cronbach's alpha value of 0.8

The main statistical method used was the regression analysis. In order to carry it out, six compound variables were entered for the factors of information technologies, innovation, trading efforts, human resources, quality and technology. ${ }^{1}$ The general equation is:

$$
\boldsymbol{V}=a+\sum_{i=0}^{n} T I+\sum_{i=0}^{n} I N+\sum_{i=0}^{n} C+\sum_{i=0}^{n} R+\sum_{i=0}^{n} C+\sum_{i=0}^{n} T
$$

This facilitates the interpretation of results and also, it is possible to establish, by using the method of main components analysis ${ }^{2}$, the weighting of each individual variable and its effect in each coefficient of the factor from the resulting equation.

The use of a regression equation allows: firstly, identifying the variables that provide its own validity; and secondly, to determine which variables have a higher impact in the response variable (sales). All this will facilitate the presentation of results to the businessmen of each economic activity.

\section{Hypotheses}

H1: Increasing the innovation efforts has a higher impact in sales than increasing the efforts in trading factors.

H2: Increasing the innovation efforts produces a raise in sales.

\footnotetext{
${ }^{1}$ All the values of each question are taken with each factor in order to obtain the sum of the same elements. These new variables are used to carry out the regression analysis.

${ }^{2}$ This analysis is used to obtain the saturation of each question about a specific factor.
} 
H3: Strengthening the efforts of the trading activity has a positive influence in sales.

H4: Increasing the investment in advertising and giving the responsibility to a supervisor from the marketing area has a positive effect on sales.

H5: Increasing the automation processes and the development of new products has a positive effect on sales.

Information for the variables of technology, financial aspects and company's growth, human factor, costs, production processes, innovation and information systems was obtained along with the aspects that define marketing (price, product market place, and advertising).

\section{Definition and Measurement of Variables}

To calculate the variable Information and Communication Technologies (ICT). The use of management systems in each one of the areas of the enterprises, the existence of any system for decision-making and the presence of software for the control of processes in each area were taken into account (located in questions 16, 17, 18, and 38).

To calculate the variable Innovation (IN). The perception of necessity to implement information systems, the percentage of automated processes and the existence of facilities for the development of new products were taken into account (located in questions 19, 43, and 45).

To calculate the variable Trading Efforts (TE). The competition's perception of the product or service, the investment in advertising, the existence of a marketing department, the investment in advertising and any record of intellectual property were taken into account (located in questions 20, 23, 24, 25, and 47).

To calculate the variable Human Resources (HR). The seniority of the manager, his/her academic degree, the number of languages used and the existence of a general plan for training were taken into account (located in questions 12, 13, 14, and 43.3).

To calculate the variable Q (Quality). The very existence of the department of quality, the development of processes and their specifications, as well as the existence of a cost reduction program associated with the quality were taken into account (located in questions 41, 42, and 43).

To calculate the variable $\mathrm{T}$ (technology). The frequency of maintenance, the perception of the status of equipments and machinery as well as the facilities of the enterprise were taken into account (located in questions 32, 33, and 36).

The variable that reflects growth was evaluated with the concept of Annual Sales (AS) (question 47).

\section{Results}

The first considerations needed for some of the factors to be included in the regression equation are, firstly, that they provide statistical validity (see Table 9).

Table 9

Statistical Validity of the Enterprise

\begin{tabular}{|l|l|l|l|l|l|l|l|}
\hline Metal-mechanics case & AS & TE & IN & T & Q & HR & ITC \\
\hline Significant & Yes & Yes & Yes & Yes & No & No & Yes \\
\hline
\end{tabular}

The next step was to obtain the equation that represents the behavior of the metal-mechanics sector:

$$
\mathrm{AS}=3.79+0.94 \mathrm{TE}+1.25 \mathrm{IN}-1.25 \mathrm{~T}-2.18 \mathrm{ICT}
$$


In order to isolate the impact from the variables IN and TE, it is necessary to set the values of the other variables. Therefore, the average values of each one were used $(\mathrm{T}=2.43)$, (ICT $=1.32)$ (see Table 10$)$. This reduces the equation to:

$$
\mathrm{AS}=-2.12+0.94 \mathrm{TE}+1.25 \mathrm{IN}
$$

Table 10

Average Values of the Enterprise

\begin{tabular}{lllllll}
\hline & TE & IN & T & ICT & Value of AS $^{3}$ & Lower \& upper limits \\
\hline Average obtained in the survey & 1.50 & 1.74 & 2.43 & 1.32 & 1.5 & \\
Value to calculate the equation & $\mathbf{3 . 0}$ & $\mathbf{3 . 0}$ & 2.43 & 1.32 & $\mathbf{4 . 5}$ & 3.8 a 5.0 \\
Setting the value of IN & $\mathbf{3 . 0}$ & 1.74 & 2.43 & 1.32 & $\mathbf{2 . 9}$ & 2.2 a 3.5 \\
Setting the value of C & 1.50 & $\mathbf{3 . 0}$ & 2.43 & 1.32 & $\mathbf{3 . 1}$ & 2.4 a 3.7 \\
\hline
\end{tabular}

Notes. Source: Own contribution, with data obtained from the survey. Bold words in this table mean the values above the average value of the Likert scale used in this investigation (maximum 5 and minimum 1).

If it is considered that the response scale follows Likert scale from 1 to 5 , where the highest value represents higher efforts of each variable, then the estimate halfway of the scale (3) was made in comparison to the medium values.

In order to be sure that the values represent accurately the possible scenario of improvement, it can consider the values of the lower limit in a way that any of the three exceeds the sales value obtained from the applied survey (1.5) which places it close to the annual five million pesos.

If it is taken into consideration that each one of the variables (IN, TE) is made of different sub-variables (see Table 11), each one with a different weighting ${ }^{4}$.

Table 11

Weighting for Innovation Efforts and Trading Activity efforts

\begin{tabular}{lll}
\hline Innovation Efforts (IN) & $\%$ & 28 \\
\hline Perception of necessity to implement information systems & $100 \%$ \\
Percentage of automated processes and existence of facilities for the development of new products & 72 & $\%$ \\
Trading Activity Efforts (TE) & 40 \\
Competition's perception of the product & 38 & $100 \%$ \\
Existence of a marketing department and Amount of Investment in Advertising & 22 \\
Records of intellectual property & \\
\hline
\end{tabular}

Note. Source: Own contribution, with data obtained from the survey.

In this way, it is substituted the data to analyze the isolated effects of the selected sub-variables so it's obtained the following (see Table 12).

Table 12

Isolated Effects of Weighting for Innovation Efforts and Trading Activity efforts

\begin{tabular}{lcc}
\hline & Value of AS & Lower \& upper limits \\
\hline $\begin{array}{l}\text { Percentage of automated processes and existence of facilities for the development of } 2.0 \\
\text { new products }\end{array}$ & 1.4 a 2.6 \\
Existence of a marketing department and Amount of Investment in Advertising & 1.1 & 0.5 a 1.8 \\
\hline
\end{tabular}

${ }^{3}$ AS = Annual Sales in millions of pesos, where 1 = less than two millions; 2 = between two and ten millions; $3=$ between ten and thirty millions; 4 = between thirty and seventy millions; and 5 = more than seventy millions.

${ }^{4}$ The weighing was obtained from the analysis of main components (varimax rotation), adding the saturations of each factor (absolute value). 
When only some of the sub-variables are considered, and using as a realistic measure the lower limit, it can be seen that there is not a positive impact in sales and it actually decreases their values.

\section{Discussions of Results}

The obtained results give enough evidence to locate the proposed hypotheses in the categories of Reject or Not Reject depending on the fulfillment of the statements (see Table 14).

Table 14

Hypothesis and Results

\begin{tabular}{|l|l|}
\hline Hypothesis & Result \\
\hline $\begin{array}{l}\mathrm{H}_{1} \text { : Increasing the innovation efforts has a higher impact on } \\
\text { sales than increasing the efforts in trading factors. }\end{array}$ & $\begin{array}{l}\text { Reject } \mathrm{H}_{1} \\
\text { There is not a significant difference that supports a higher impact due } \\
\text { to innovation. The variations are } 2.9 \text { and } 3.1 \text { in the value of sales }\end{array}$ \\
\hline $\begin{array}{l}\mathrm{H}_{2}: \text { Increasing the innovation efforts produces a raise in } \\
\text { sales. }\end{array}$ & $\begin{array}{l}\text { Not Reject } \mathrm{H}_{2} \\
\text { The value of sales changed from } 1.5 \text { to } 3.1\end{array}$ \\
\hline $\begin{array}{l}\mathrm{H}_{3}: \text { Strengthening the efforts of the trading activity has a a } \\
\text { positive influence on sales. }\end{array}$ & $\begin{array}{l}\text { Not Reject } \mathrm{H}_{3} \\
\text { The value of sales changed from } 1.5 \text { to } 2.9\end{array}$ \\
\hline $\begin{array}{l}\mathrm{H}_{4}: \text { Increasing the investment in advertising and giving the } \\
\text { responsibility to a supervisor from the marketing area has a a } \\
\text { positive effect on sales. }\end{array}$ & $\begin{array}{l}\text { Reject } \mathrm{H}_{4} \\
\text { The value of sales changed from } 1.5 \text { to } 1.1\end{array}$ \\
\hline $\begin{array}{l}\mathrm{H}_{5}: \text { Increasing the automation processes and the development } \\
\text { of new products has a positive effect on sales. }\end{array}$ & $\begin{array}{l}\text { Not Reject } \mathrm{H}_{5} \\
\text { The value of sales changed from } 1.5 \text { to } 2.0\end{array}$ \\
\hline
\end{tabular}

\section{Conclusions}

The researches related to the behavior, performance or characteristics found in SMEs in Aguascalientes can only be considered useful if the results obtained are interpreted and duplicated for a larger number of enterprises so it can produce general characteristics and behaviors. That is why the analyzed data are, from the point of view of the authors, sufficient to deduce recommendations that the people in charge will evaluate to determine whether they will take the necessary steps to get a competitive advantage. One of the characteristics of the strategies, according to Markides (1999), is that they are circumscribed in a process of dynamic improvement where achievements and success must be checked constantly with the objectives created by the same enterprise. It is also necessary to consider the impact and specific value of each resource (Prahalad \& Hamel, 1990), the creator of competences that sustain the competitive advantages of each enterprise in their activities sector or in their classification by size.

The variable CIT, HR, and Quality must be analyzed by the enterprises because which can classifying them by size, there are correlated in any of the two ways to measure the company's growth. Even when H3 was rejected, there is no doubt that management training is an element that is considered as a valuable resource (Barney, 1991; Álvarez, 2003; Cuervo, 2004) that can provide information to take advantage of the growth opportunities and the market placing.

\section{References}

Aguilera, E. L. (2009). Innovation and development of processes and products for SMEs in strategic sectors (Innovación y Desarrollo de Procesos y Productos para las Pymes de Sectores Estratégico). Aguascalientes, México.

Álvarez, M. M. (2003). Core competencies and competitive advantage: The concept, its evolution and its applicability (Competencias Centrales y Ventaja Competitiva: el concepto, su evolución y su aplicabilidad). Revista Contaduría y 
Administración, 209, 5-22.

Andrews, K. R. (1998). The concept of corporate strategy. In H. Mintzberg, J. B. Quinn, \& S. Ghoshal (Eds.), The Strategy Process: Revised European Edition (pp. 51-59). London, Prentice Hall Europe.

Aragón Sánchez, A. (2005). Factors associated com the competitive success of industrial SME’s in Spain (Factores Asociados com el éxito competitivo de las PYME's industriales en España). Revista Universia Business Review, Departamento de Organización de Empresas y Finanzas, 1(8), 38-50.

Barney, J. (1991). Firm resources and sustained competitive advantage. Journal of Management, 17(1), 99-120.

Beaver, G. (2007). The strategy payoff for smaller enterprises. Journal of Business Strategy, 28(1), 11-19.

BID-IKEI. (2005). Responsibility Corporate Social in SME's of Latin America (Responsabilidad Social de la Empresa en las PYME's de Latinoamérica). Washington, D. C.: Banco Interaméricano de Desarrollo-Instituto Vasco de Estudios e Investigación.

Blázquez, F., Dorta, J., \& Verona, M. (2006). Concept, perspectives and measurement of the growth business (Concepto, Perspectivas y Medida del Crecimiento Empresarial). Cuadernos de Administración, 19, 165-195.

Burgelman, R. (2002). Strategy is destiny: How strategy-making shapes a company's future. New York: The Free Press.

Cuervo G., A. (2004). Business creation: On employers (Creación Empresarial: Sobre Los Empresarios). Madrid, España: Universidad Complutense De Madrid.

Hamel, G. (1996). Strategy as revolution. Harvard Business Review Jul.-Ago., 74(4), 69-82.

Hamel, G., \& Prahalad, C. (1994). Competing for the future. U.S.A.: Harvard Business School Press.

Haugstad, B. (1999). Strategy theory: A short review of the literature. SINTEF Industrial Management (pp. 1-9). The SINTEF "Living Knowledge" Strategic Institute Program.

INEGI. (2009). View statistics of Aguascalientes (Perspectiva Estadística de Aguascalientes). Ags.: Instituto Nacional de Geografía Estadística e Informática.

INEGI. (2010). Economic information bank (Banco de Información Económica). Retrieved April 24, 2010, from http://dgcnesyp.inegi.org.mx/bdiesi/bdie.html

Markides, C. C. (1999). A dynamic view of strategy. Sloan Management Review. Massachusetts Institute of Technology, 40(13), $55-63$.

Ministery of Economy (Secretaría de Economía) (SE). (2009). Mexican business information system (Sistema de Información Empresarial Mexicano). Retrieved from http://www.siem.gob.mx/siem/portal/consultas/ligas.asp?Tem=5

Munive, H. E., Dewhurst, F., Pritchard, M., \& Barber, K. (2004). Modelling the strategy management process: An initial BPM approach. Business Process Management Journal, 10(6), 691-711.

Penrose, E. T. (1952). Biological analogies in the theory of the firm. American Economic Association, 42(5), 804.

Penrose, E. T. (1959). The theory of the growth of the firm. Gran Bretaña: Oxford University Press.

Prahalad, C., \& Hamel, G. (1990). The core competence of the corporation. Harvard Business Review May-June (pp. 1-15).

Quinn, J., \& Voyer, J. (1998). Logical incrementalism: Managing strategy formation. H. Mintzberg, J. B. Quinn, \& S. Ghoshal (Eds.), The Strategy Process (pp. 103-110). London: Prentice Hall Europe.

Rojo, M., \& González, G. (2007). Growth business via co-operations between companies: Empirical study on the Spanish tourism sector (El crecimiento empresaria vía cooperaciones entre compañias. Estudio empírico sobre el sector turístico español). Investigaciones Europeas de Dirección y Economías de la Empresa, 13(3), 127-145.

Sánchez, B. G. (2009). Micro and small Mexican companies to the crisis of the economic paradigm of 2009 (Las micro y pequeñas empresas mexicanas ante la crisis del paradigma económico de 2009). Málaga, España: Edición electrónica gratuita. Retrieved from http://www.eumed.net/libros/2009a/524/

Taboada, I. E. (2004). What is behind the decision to cooperate technologically? (Qué Hay Detrás De La Decisión De Cooperar Tecnológicamente?) (Tesis doctoral, México, D.F.: Universidad Autónoma Metropolitana). 